\title{
Cerebral toxoplasmosis after haematopoietic stem cell transplantation
}

\author{
Agnieszka Zaucha-Prażmo' ${ }^{1}$, Marzena Samardakiewicz'1, Joanna Dubelt ${ }^{2}$, Jerzy R Kowalczyk' \\ ${ }^{1}$ Department of Paediatric Haematology, Oncology and Transplantology, Medical University, Lublin, Poland \\ 2 Department of Paediatric Neurology, Medical University, Lublin, Poland
}

Zaucha-Prażmo A, Samardakiewicz M, Dubelt J, Kowalczyk J R. Cerebral toxoplasmosis after haematopoietic stem cell transplantation. Ann Agric Environ Med. 2017; 24(2): 237-239. doi: 10.5604/12321966.1232086

\section{Abstract}

Toxoplasmosis is an opportunistic infection caused by the parasite Toxoplasma gondii. The infection is severe and difficult to diagnose in patients receiving allogeneic haematopoietic stem cell transplantation (HSCT). It frequently involves the central nervous system. The case is presented of cerebral toxoplasmosis in a 17-year-old youth with Fanconi anaemia treated with haematopoietic stem cell transplantation (HSCT).

\section{Key words}

toxoplasmosis, Fanconi anaemia, haematopietic stem cell transplantation

\section{INTRODUCTION}

Toxoplasmosis is an opportunistic infection caused by a parasite Toxoplasma gondi. Infection in an immunecompetent host leads to latency of the parasite as cysts in various organs. Severe infection occurs in highly immunocompromised patients, mostly by reactivation of latent cysts, but also as a primary infection $[1,2]$. Toxoplasmosis in patients following haematopoietic stem cell transplantation (HSCT) is a rare, but life-threatening infection, with a high mortality rate [3]. It frequently involves the central nervous system, both as an isolated cerebral infection, or in a disseminated disease [1, $2,4]$. It may also affect intellectual abilities in some patients. The case is presented of cerebral toxoplasmosis, diagnosed in the post-transplant period in a youth with Fanconi Anaemia (FA), transplanted from a matched unrelated donor.

Demographical data. A 17-year-old youth was diagnosed as having Fanconi Anemia (FA) in adolescence, at the age of 15 years. The youth was living in a rural area, with an older healthy brother, both parents and grandmother. During treatment, the patient's family received psychosocial support from family members and friends. The socio-economical status of patient's family was good. The parents had a high level of education, but the patient had school difficulties before treatment. There was no data on toxoplasmosis infections in the other family members.

HSCT status. Six months after diagnosis of FA, the patient underwent allogeneic HSCT from a 10/10 matched, unrelated donor. Pre-transplant conditioning included cyclophosphamide (50 mg/kg/day for 4 consecutive days) and fludarabine $\left(35 \mathrm{mg} / \mathrm{m}^{2}\right.$ of body surface area/day for 5 consecutive days). Antithymocyte globuline and cyclosporine with short-term methotrexate were administered for Graft versus Host Disease (GvHD) prophylaxis. The pretransplant Toxoplasma gondii serostatus of the recipient was unknown, the donor was toxo-seronegative, pre-transplant

Address for correspondence: Agnieszka Zaucha-Prażmo, Department of Pediatric Hematology, Oncology and Transplantology, Medical University, Lublin, Poland E-mail: a.prazmo@umlub.pl

Received: 18 January 2016; accepted: 16 January 2017; first published on February 2017
Cytomegalovirus (CMV) serostatus of the donor and recipient were positive. The early post-transplant period proceeded without complications, except for staphylococcal bacteraemia and infection diagnosed on day 4, which resolved after antibiotic therapy. Engraftment of leucocytes as well as granulocytes were noted on day 12 post-transplant. Complete donor chimerism with PCR method was found on day 10 and maintained until now. Acute graft versus host disease (aGvHD) was not observed. The patient was discharged from hospital on day 30 post-transplant. A week later, every evening, fever episodes started. Diagnostic procedures towards infections, including imaging studies, e.g. abdominal ultrasononography as well as thoracic and abdominal computer tomography (CT), were negative. As well as C-reactive protein, bacteriology and viral tests, except for positive Ebstein-Barr virus (EBV) PCR test. EBV reactivation resolved after 2 weeks of preemptive treatment with rituximab. GvHD prophylaxis was discontinued at day 120 . Three months post-transplant, visual impairment occurred. Changes on the retina during eye examination: macular oedema, retinochoroidal scars were found, and chorioretinitis of the right eye was diagnosed. Toxoplasmosis serology test by the chemiluminescence method was negative in $\operatorname{IgM}(<0.9 \mathrm{IU} / \mathrm{ul})$, and positive in $\operatorname{IgG}(37.7 \mathrm{IU} / \mathrm{ml})$ at that time. Tests are considered positive when IgG or IgM titers exceed $10 \mathrm{IU} / \mathrm{ml}$. According to the clinical signs of ocular infection, anti-toxoplasma treatment with clindamycine and trimetoprime was started. After 2 weeks of combined treatment no clinical improvement was obtained, visual impairment maintained and chronic fever episodes were observed. At the same time, toxo serology became strongly positive (IgM $1100 \mathrm{IU} / \mathrm{ul}$ and IgG $14.43 \mathrm{IU} / \mathrm{ml}$ ), and persisted for next 2 months despite continuing treatment (Tab. 1).

Neurologic status. Six months post-transplant, the youth was found at home with consciousness disorders, periodically without logical contact, with symptoms of sensory aphasia. On admission to hospital, the patient complained of headache, malaise, discomfort, myalgias, abdominal and inguinal pain and chronic fever. Toxo-serology was still positive (IgM -15.70 $\mathrm{IU} / \mathrm{ml}$ and $\mathrm{IgG}-242 \mathrm{IU} / \mathrm{ml}$ ). Cerebral computer tomography (CT) and magnetic resonance imaging (MRI) scans showed 
Table 1. Results of serology tests for toxoplasmosis in postransplant period

\begin{tabular}{ccc}
\hline Month postransplant & Toxo $\operatorname{lgG}[\mathrm{IU} / \mathrm{ml}]^{*}$ & Toxo $\lg \mathrm{M}[\mathrm{IU} / \mathrm{ml}]^{*}$ \\
\hline 3 & 37.7 & $<0.9$ \\
\hline 4 & 1100 & 14.43 \\
\hline 6 & 242 & 15.7 \\
\hline 12 & $>700$ & 7.85 \\
\hline 18 & $>700$ & 1.41 \\
\hline 24 & $>700$ & 1.13 \\
\hline
\end{tabular}

*Toxo IgG, IgM values range: negative $<6.4 \mathrm{IU} / \mathrm{ml}$; doubtful $6.4-9.9 \mathrm{IU} / \mathrm{ml}$; positive $>10.0 \mathrm{IU} / \mathrm{ml}$

multifocal calcifications in left and right occipital lobes, in the frontal lobe, in temporal lobes and in the left parietal lobe. The biggest calcification was located subcortical in frontal lobe with an accompanying zone of increased signal (cytotoxic oedema susp.). Such images are seen not only in cerebral reactivation of toxoplasmosis, but also in cryptococcosis and aspergillosis. Electroencephalography (EEG) recording was incorrect with localized changes. In cerebrospinal fluid (CSF), pleocytosis (47/ul) with limfocytosis (95\%) was found, protein was raised and Pandy reaction positive. Toxo-serology in CSF was also positive (IgM $0.65 \mathrm{IU} / \mathrm{ml}, \mathrm{IgG} 21 \mathrm{IU} / \mathrm{ml})$. The serological method used for diagnosis of toxoplasmosis in the presented case is the chemiluminescence method, with the following values range: negative $<6.4 \mathrm{IU} / \mathrm{ml}$, doubtful 6.4-9.9 IU/ml, positive > 10.0 IU/ml. Toxo-PCR tests were negative, both in CSF and in the blood, as well as other PCR tests for CMV, EBV and cryptococcus. For diagnosis, PCR Real-Time qualitative method was used.

Intensive antiprotozoal treatment with high doses of trimetoprime and dexamethasone was introduced and continued for 6 months. Clinical status gradually improved, neurological symptoms resolved, as well as MRI symptoms, but toxoplasma serology tests remained highly positive, especially in IgG. The results of serology test for toxoplasmosis in post-transplant period are shown in Table 1. The patient is now in a good clinical condition, his neurological status is normal, changes in the eye resolved completely, leaving changes typical for ocular toxoplasmosis cicatricle.

Psychological status. From the beginning of hospitalization, the patient was under planned psychological and psychosocial care. Both intelligence quotient (IQ) and quality of life (QL) were examined before and after HSCT procedure, according to the established model of care [5]. Quality of life level was additionally examined 6 months post-transplant, due to toxoplasmosis infection. Respectively, Wechsler's scales (WISC-R and WAIS-R PL) as measure of intelligence, and The Short Form (36) Health (SF-36) as a measure of health status, were used. Additionally, psychosocial adaptation of the patient's family was checked using the PAT 2.0 questionnaire [6]. The level of the youth's pre-transplant general intellectual ability (Full Scale IQ) was average $(F S I Q=91)$, with significant imparity between Verbal IQ $(\mathrm{VIQ}=100)$ and Performance IQ $(\mathrm{PIQ}=83)$. In post-transplant IQ scores, a small increase was observed in FSIQ, PIQ, and VIQ levels, sustaining the same tendency. Low scores in the Performance Scale subtests may have an organic basis due to the long-standing periods of anaemia. In the quality of life measurement, high scores were stated 6 months posttransplant, after toxoplasmosis infection. In the Polish
Version of the SF-36 Questionnaire, the higher the score the more disability in the patient's health status. Detailed patient's intelligence and quality of life characteristics in different treatment stages are presented in Table 2.

Table 2. Patient's intelligence and quality of life characteristics in different treatment stages

\begin{tabular}{lcccccc}
\hline Treatment stage & \multicolumn{3}{c}{ Intelligence } & \multicolumn{3}{c}{ Quality of life } \\
\hline & FSIQ & VIQ & PIQ & $\begin{array}{c}\text { Health } \\
\text { status }\end{array}$ & $\begin{array}{c}\text { Physical } \\
\text { Health }\end{array}$ & $\begin{array}{c}\text { Mental } \\
\text { Health }\end{array}$ \\
\hline pretransplant & 91 & 100 & 83 & 18 & 2 & 2 \\
\hline 6 months posttransplant & & & & 105 & 30 & 39 \\
\hline 24 months posttransplant & 103 & 113 & 90 & 23 & 1 & 2 \\
\hline
\end{tabular}

FSIQ - Full Scale Intelligence Quotient

VIQ - Verbal Intelligence Quotient

PIQ - Performance Intelligence Quotient

IQ ranges in Wechsler's Scales: Low Average [80-89]; Average [90-110]; High Average [110-119]

\section{DISCUSSION}

Fanconi Anaemia is autosomal recessive or X-linked congenital disease, characterized by progressive bone marrow failure, developmental defects, predisposition to malignancy and different alterations in immunologic function (impairment of T-cell function, NK and macrophage function [7,8]. Haematopoietic stem cell transplantation may be associated with several complications, including neurologic, which may be secondary to the treatment toxicity, prolonged immunosuppression or an underlying disease. Common neurologic complications are infections, including toxoplasmosis. Recent studies showed that toxoplasma disease may develop from $0.25-4 \%$ allotransplant recipients, with a mortality rate as high as $60-90 \%[3,4,9,10,11,12$, 13]. PCR techniques have been developed for noninvasive diagnosis, also in cerebral toxoplasmosis, which contribute to rapid diagnosis and monitoring of treatment efficacy $[1,2,9$, $10,11,13,14,15,16]$. Some authors, however, still emphasize the role of serology in the diagnostics of toxoplasmosis, as well as a combination of serology and PCR techniques $[9,11]$. Serological tests are very useful before transplantation to assess serostatus of the recipient and donor, and for monitoring the recipient after transplantation [11, 13].

The question remains, why PCR test, which seemed to be very useful in the diagnosis of disseminated toxoplasmosis, as well as in cerebral toxoplasmosis, was negative in the presented case. Radiologic methods as non-invasive MRI where typical findings, such as multiple, ring-enhancing brain lesions often associated with oedema, may facilitate or confirm the diagnosis in the context of serological or PCR tests. However other infections, such as aspergillosis and cryptococcosis, may cause similar lesions; therefore, combined diagnostic tools need to be used to enable correct diagnosis and to start proper treatment. The patient in the presented had probable cerebral toxoplasma disease, diagnosed according to clinical symptoms preceded by retinochorioiditis, radiologic evidence of brain involvement and positive toxo-serology from CNF in the acute phase of the disease, but not with the PCR tests which were negative, both from the blood and CSF. Good response for anti-toxo therapy may confirm the diagnosis. The good result of the treatment may also be due to the recovery of the immune system (CD4>100/ul during the first month of the treatment). 
Fanconi anaemia is commonly associated with a range of neurological and developmental issues characterized by mild to significant impairment, such as attention deficit, hyperactivity disorder (ADHD), learning disabilities, and developmental delay $[18,19]$. In the current case, only mild learning difficulties and periodic decrease in quality of life were observed due to cerebral toxoplasmosis. However, any young person (child or youth) with FA and learning disabilities, especially after HSCT procedure, should be monitoring for psychosocial functioning.

\section{CONCLUSIONS}

The toxoplasmosis status should be monitored in patients treated with HSCT, especially in seropositive recipients transplanted from seronegative donors, to introduce preemptive therapy which may help to reduce the risk of developing disseminated or cerebral disease. The principle of pre-emptive therapy is to prevent development of the disease, not to prevent infection, in very high risk patients. This is particularly important early post-transplant when patients are highly immunocompromised.

\section{REFERENCES}

1. Meers S, Lagrou K, Theunissen K, Dierickx D, Delforge M, Devos T et al. Myeloablative conditioning predisposes patients for Toxoplasma gondi reactivation after allogeneic stem cell transplantation, Clin Infect Dis 2010; 50:1127-1134.

2. Martino R, Bretagne s, Einsele H, Maertens J, Ulmann AJ, Parody R et al. Early detection of Toxoplasma infection by molecular monitoring of Toxoplasma gondii in peripheral blood samples after allogeneic stem cell transplatation. Clin Infect Dis 2005; 40:67-78.

3. Mulanovich VE, Ahmed SI, Ozturk T, Khokhar FA, Kontoyiannis DP, de Lima M. Toxoplasmosis in allo-SCT patients: risk factors and outcomes at a transplantation center with a low incidence. Bone Marrow Transplant. 2011; 46(2): 273-277.

4. Voegele L, Cheerva AC, Bertolone S. Cerebral toxoplasmosis after tandem high-dose chemotheraphy and autologous hematopoietic cell transplant for neuroblastoma. J Pediatr Hematol Oncol. 2013; 35(2):e50-52.

5. Samardakiewicz M. Optymalizacja metod wspomagania biopsychospołecznego dzieci leczonych z powodu choroby nowotworowej: roz- prawa habilitacyjna. 2008, Medical University, LublinLublin 2008, Uniwersytet Medyczny w Lublinie,

6. Kazak, A., Barakat, L., Ditaranto, S., Biros, D., Hwang, W.T., Beele, D, Kersun L, Alderfer MA, Mougianis I, Hocking MC, Reilly A.. Screening for psychosocial risk at cancer diagnosis. Psychosocial Assessment Tool (PAT). J Ped Hemat, 2011; 33(4) 289-294.

7. Liu Y, Ballman K, Khan S, Derr-Yellin E, Shou W, Haneline LS. Impared function of Fanconi anemia type C-deficient macrophages. J Leukoc Biol 2012; 91(2):333-3340.

8. Myers KC, Bleesing JJ, Davies SM, Zhang X, Martin LJ, Mueller R, et al. Impaired immune function in children with Fanconi anaemai. Br J Haematol. 2011; 154(2):234-240.

9. Fricker-Hidalgo H, Bulabois CE, Brennier-Pinchart MP, Hamidfar R, Garban F, Brion JC et al. Diagnosis of toxoplasmosis after allogeneic stem cel transplantation: result of DNA detection and serological techiques. Clin Infect Dis 2009; 48:e9-15.

10. Lim Z, Baker B, Zuckermann M, Wade JJ, Ceesav M, Ho AY et al. Toxoplasmosis following alemtuzumab-based allogeneic haematopoietic stem cell transplantation. J Infect 2007; 54:E83-86.

11. Walker M, Zunt J. Parasytic central nervous system infection in immunocompromised host. Clin Infect Dis 2005; 40:1005-1015.

12. Hakko E, Ozkan HA, Karaman K, Gulbas Z. Analysis of cerebral toxoplasmosis in a series of 170 allogeneic hematopoietic stem cell transplant patients. Transpl Infect Dis. 2013; 15(6):575-580.

13. Sumi M, Aosai E, Norose K, Takeda W, Kirihara T, Sato K et al. Acute exacerbation of Toxoplasma gondii infection after hematopoietic stem cell transplantation: five case reports among 279 recipients. Int J Hematol. 2013; 98(2):214-222.

14. Stajner T, Vasiljevic Z, Vujic D, Markovic M, Ristic G, Micic D et al. Atypical strain of Toxoplasma gondi causing fatal reactivation after hematopoietic stem cell transplantation in a patient with an underlying immunological deficiency. J Clin Microbiol. 2013; 51(8): 2686-2690.

15. Caselli D, Andreoli E, Paolicchi O, Savelli S, Guidi S, Pecile P et al. Acute encephalopathy in the immune-compromised child: never forget toxoplasmosis. J Pediatr Hematol Oncol. 2012; 34(5): 383-386.

16. Rossi CL, Nascimento FS, de Barros-Mazon S, Dias DF, Vigorito AC, de Souza CA. Serological monitoring of a Toxoplasma infection after hematopoietic stem cell transplantation. Rev Inst Med Trop. 2010; 50(4):225-227.

17. Cavattoni I, Ayuk F, Zander AR, Zabelina T, Bacher A, Cayroglu E et al. Diagnosis of Toxoplasma gondii infection after allogeneic stem cell transplan can be difficult and requires intensive scrutiny. Leuk Lymphoma. 2010; 51(8):1530-1535.

18. Kearney JA, Hay JL, Halpern L, Boulad F. Peritransplant psychiatric evaluation of patients with Fanconi anemia. J Ped Hematol Oncol. 2012; 34(3):163-168.

19. Cincotta NF, Psychosocial Issues [W:]. Hays L (ed) Fanconi Anemia:Guidelines for Diagnosis and Management. Fanconi Anemia Ressearch Foundation, Fourth Edition 2014, p.333-352. 